\title{
Of Wounded Bodies and the Old Manchu Archive: Documenting Personnel Management in the Early Manchu State ${ }^{1}$
}

\author{
HE BIAN \\ Depts. of History and East Asian Studies, Princeton University
}

This article examines the only bilingual component in the Old Manchu Archive-the record of 228 officers and soldiers' battle wounds, as well as Nurhaci's decision to reward them after he became khan in 1616. Departing from previous scholarship that highlights the historiographical impulse that shaped these pre-conquest documents, I argue that the compilation of archival materials (dangse) under the nascent Latter Jin state was also motivated by the need to recognize the meritorious deeds of military personnel and manage their ranks and privilege in writing. The enigmatic presence of a Manchu-only copy of the battle wound documents, which bears marginal notes concurrent with its active use as a ledger, indicates the rise of a more standardized system of military administration and the ascent of Manchu script as the dominant language for documentation.

\section{負傷的身體與 《舊滿洲檔》：早期滿洲國家形成中的人事紀錄 邊和 \\ 普林斯頓大學歷史系及東亞研究系 \\ 摘要}

本文考察《舊滿洲檔》中僅見的一批滿漢隻語文書及其滿文複本（ “寒字 檔”1-42葉）。雙語文書中記載了二百二十八名軍官及士兵在作戰中負傷的類 型及數目, 以及努爾哈赤給予他們的賞賜。以往研究中多強調後金及清代修 訂國史對檔案形態及內容的影響, 而本文意在指出後金檔冊的形成亦出於軍 事化人事管理之需要。此外, 雙語文書的滿文複本存在大量對數目字紀錄的 塗改，顯示該文書曾被作為軍功簿頻繁使用，亦說明後金國家的人事管理逐 漸趨於標準化、滿文的應用趨於普遍化。

1. I would like to thank the organizers and audience at the 2016 Manchu Studies Conference held at the University of Michigan for their initial comments. My gratitude also goes to Beatrice Bartlett, Susan Naquin, Nicola di Cosmo, Hasegawa Masato, José Andrés Alonso de la Fuente, and the audience at the 2017 Princeton East Asian Studies lunch colloquium for their feedback. Mårten Söderblom Saarela and Eric Schluessel carefully edited the article. All remaining errors are mine. 
In 1931, researchers in Beijing discovered a set of documents from the former depositories of the Qing Grand Secretariat. The thirty-one volumes, covered with yellow paper, were predominantly written in Old Manchu (tongki fuka akü hergen "characters without circles and dots") and chronicled events and edicts during the Tianming (16161626) and Tiancong (1627-1635) reigns. On the same shelf were a second set of yellow silk-covered documents written in standard Manchu (tongki fuka sindaha hergen "characters with circles and dots"), identical to those discovered in 1905 by the Japanese scholar Naitō Torajirō 内藤虎次郎 (Konan 湖南, 1866-1934) in the Mukden Palace. We now know that the standard Manchu documents were completed on the Qianlong emperor's order by 1780 as part of his longstanding effort to keep the old script legible. The 1931 discovery of the "original documents" (yuandang 原檔) in Old Manchu gave a competitive edge to Chinese historians vis-à-vis their Japanese counterparts with regard to the early history of the Qing dynasty, a subject made more sensitive given the imminent enthronement of Puyi as the figurehead of Manchukuo the following year. ${ }^{2}$

Since then, the so-called Old Manchu Archive (Jiu Manzhou dang 舊滿洲檔, originals in Taipei) and the Qianlong Standard Manchu duplicates (Ch. Manwen laodang, Ja. Manbun rōtō 滿文老檔) became arguably the single most important source for the rise of Jurchen power in early seventeenth century Northeast Asia. ${ }^{3}$ As the earliest extant examples of the script since its adaptation from Mongolian letters in the late 1590s, the documents shed light on evolving features of the Manchu language, before the familiar form with diacritics was consolidated in the 1630s and further standardized through the dynasty's rule. ${ }^{4}$ Early research and translations of Jiu Manzhou dang (JMZD) and Manbun rōtō (MBRT) have deeply shaped our standard narrative of pre-

2. For the discovery and study of Qing documents in Republican China, see Beatrice Bartlett, "Saving China's History: The Discovery and Debate Concerning the Sorting and Arranging of the Qing Archives, and their eventual dispersion, 19121949," lecture at Princeton University (March 8, 2016); and idem., “Qingdai dang'an lunshu de huigu: 1616-1999” 清 代檔案論述的回顧: 1616-1999, in Fu an de lishi: Dang'an kaojue yu Qing shi yanjiu 覆案的歷史: 檔案考掘與清史研 究, ed. Chen Hsi-yuan 陳熙遠 (Taipei: Academia Sinica, 2013), 1-58. For the sensitivity of pre-Conquest Qing history in Republican China, see Madeleine Yue Dong, "How to Remember the Qing Dynasty," in The Politics of Historical Production in Late Qing and Republican China, eds. Tze-ki Hon and Robert J. Culp (Leiden: Brill, 2007), 323-74.

3. For foundational studies that compared the Old Manchu and standard Manchu documents, see Kanda Nobuo 神田信 夫, "From Man-wen lao-tang to Chiu Man-chou tang," Memoirs of the Research Department of the Toyo Bunko 38 (1980): 71-94; Zhuang Jifa 莊吉發, “Wenxian zuzheng: ‘Manwen laodang' yu Qingshi yanjiu” 文獻足徵：滿文老檔與清史研 究, Manxue yanjiu 滿學研究4 (1998): 85-115 and other articles in the same issue; Guang-lu and Li Xuezhi, "Qing Taizu chao Lao manwen yuandang yu Manwen laodang zhi bijiao yanjiu” 清太祖朝老滿文原檔與滿文老檔之比較研究 in Lao Manwen yuandang lunji 老滿文原檔論集, ed. Li Xuezhi, Appendix 1 (Taipei: Academia Sinica, 1971). Liu Housheng 刘厚生, Jiu Manzhou dang yanjiu 旧满洲档研究 (Changchun: Jilin wenshi chubanshe, 1993); Yan Chongnian 阎崇年, “Wu quandian laodang' ji Qianlong chaoben yi yan shuping” 《无圈点老档》及乾隆抄本译研述评, Gugong bowuyuan yuankan (1998.3): 32-46; Kim Tu-hyŏn 金斗鉉, Manmun nodang kwa Ku manjudang taejop'yo: T'aejojo 滿文老檔欍 滿洲檔對照表: 太祖朝 (Ulsan Kwangyŏksi: Ulsan Taehakkyo ch'ulp’anbu, 2010). For Old Manchu documents beyond the JMZD, see Tatiana Pang and Giovanni Stary, New Light on Manchu Historiography and Literature: The Discovery of Three Documents in Old Manchu Script (Wiesbaden, Harrassowitz, 1998), and idem., Manchus versus Ming. Qing Taizu's "Proclamation" to the Ming Dynasty (Wiesbaden, Harrassowitz, 2010).

4. T. A. Pang, The Manchu Script Reform of 1632: New Data and New Questions, Studia Orientalia 87 (Helsinki, 1999). 201-6. 


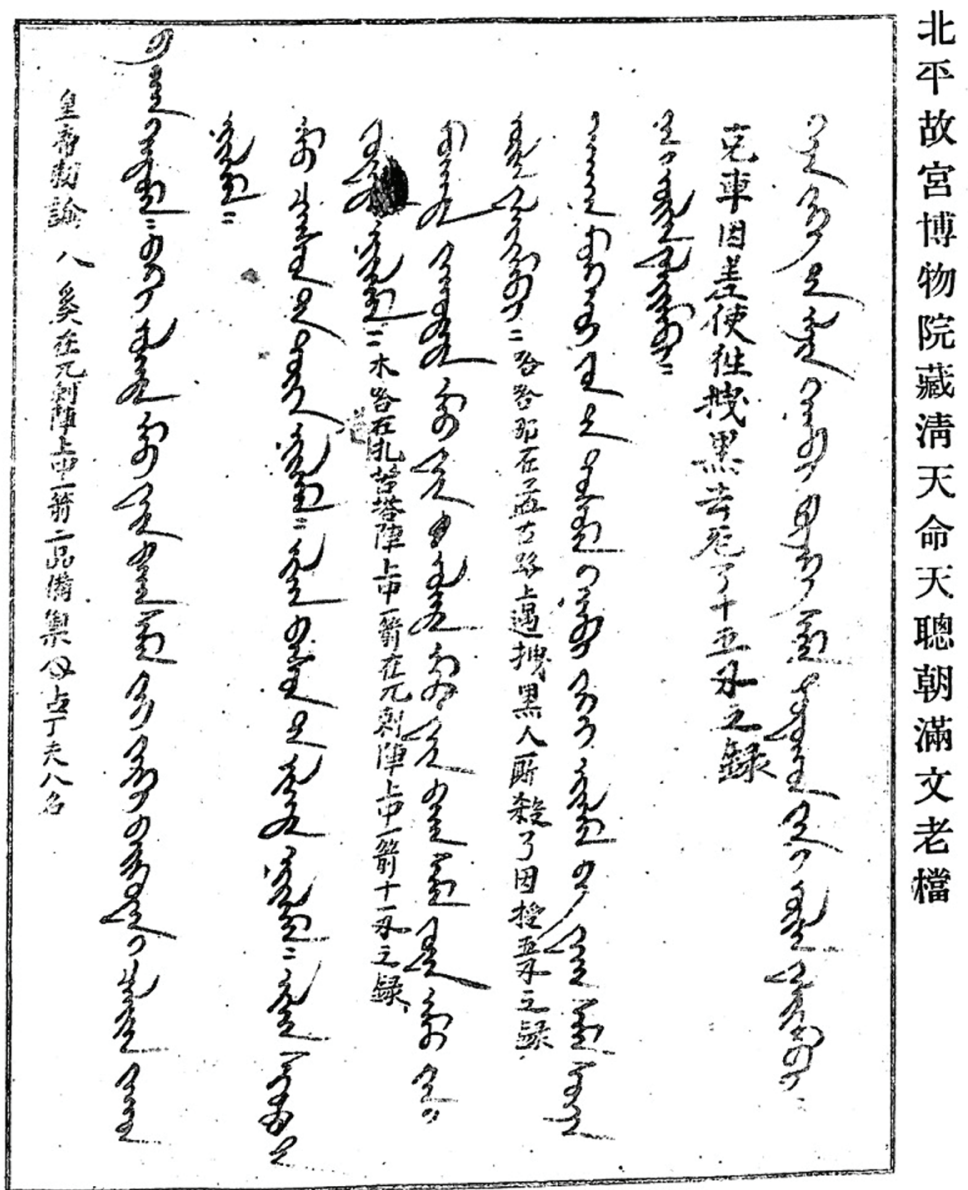

Figure 1. Photograph of bilingual documents in Xie Guozhen, Qing kaiguo shiliao kao (1930), front matter.

conquest Qing history. ${ }^{5}$ In recent years, new research on the Old Manchu Archive was greatly enhanced by the publication of a new, much clearer facsimile edition by the National Palace Museum in 2005, under the slightly different title Manwen yuandang (MWYD), as well as the First Historical Archive's publication of the Qianlong-era compilers' annotated version that reflected their interpretations of the old script (Neige cangben Manwen laodang, hereafter NGMW for Neige Manwen). ${ }^{6}$ This study primarily cites the 1969 JMZD due to its wider availability but uses images from the 2005 MWYD, with references to MWRT and NGMW, when discussing the rendering of pre-conquest language into standard Manchu.

5. See for instance Gertraude Roth Li, "State-Building Before 1644," in The Cambridge History of China, Vol. 9, Part 1, ed. Willard J. Peterson (Cambridge: Cambridge University Press, 2002), 9-72. Frederic Wakeman's The Great Enterprise (Berkeley: University of California Press, 1985) largely relied on Roth Li and Japanese scholarship on Manchu sources, and his discussion of the latter was sparse in comparison to Chinese sources.

6. Zhuang Jifa, “'Manwen yuandang,' 'Neige cangben manwen laodang'yu Qingchao qianshi de yanjiu” 《滿文原檔》、 《内 閣藏本滿文老檔》與清朝前史的研究.” In Fu an de lishi: Dang'an kaojue yu Qing shi yanjiu, ed. Chen Hsi-yuan (Taipei: Academia Sinica, 2013), 59-144. 
The Manchuness of the Old Manchu Archive, however, was not taken for granted upon the discovery of those documents in 1931. In one of the earliest published images of the records, Xie Guozhen 謝國楨 (1901-1982), then a young scholar working at the National Library in Beijing, noted the existence of "parallel Manchu and Chinese texts" 滿漢文並行 in the set (see Figure 1). Examining the originals together with renowned historian Chen Yinke 陳寅恪 (1890-1969) and Feng-kuan 奉寛 (b. 1876), a former Mongol bannerman and scholar who conducted extensive research on the Grand Secretariat collection, Xie highlighted the unconventional Chinese rendering of important tribe names such as Yehe and Ula (葉赫作拽黑、吳喇作匹刺). ${ }^{7}$ Chen Chieh-hsien 陳捷先, in his editorial introduction to the 1969 facsimile edition of JMZD, confirmed that the only volume containing bilingual documents was number 16 of the whole set, known as the Hanzidang 寒字檔 (indexed with the Chinese character han by the Qianlong-reign editors according to the order of the sequence of characters in Qianziwen 千字文 [Thousand character essay], a common bibliographical ordering tool) and dated to Tianming 9 (1624), since they were bound together with other documents composed that year. Chen also noted that many Chinese characters in the Hanzidang appeared quite "vulgar" (cusu 粗俗), even erroneous (biezi 別字). ${ }^{8}$ The Chinese parts of the Hanzidang were eliminated in the Qianlong standard Manchu edition, as the eighteenth-century editors focused primarily on increasing the legibility of the Manchu text. In this article, I use the bilingual documents of Hanzidang to highlight the transition from a polyglot culture of documentation to standardized Manchu under Nurhaci's reign. ${ }^{9}$ As discussed elsewhere by Pamela Crossley and others, the idea of a Manchu state did not coalesce until the 1630s, and the processes by which a majority population of different ancestries and linguistic capabilities subscribed to the language of a minority elite are worth further investigation. ${ }^{10}$ The bilingual records of the Hanzidang are particularly important in this regard.

Unlike the majority of entries in the Old Manchu Archive, Nurhaci's edicts (ejehe) recorded in folios 1-28 of the Hanzidang are not chronicles that documented the khan's day-to-day business. Instead, they are undated, recording battle wounds of officers and soldiers as well as the reward and privilege they received in return. Furthermore, the

7. Xie Guozhen 謝國楨, Qing kaiguo shiliao kao 清開國史料攻 (Beiping: Guoli Beiping tushuguan, 1931), Supplement, $1 \mathrm{a}-1 \mathrm{~b}$. Xie also considered the rapid growth of Jianzhou Jurchens from a small tribe to a dominant regional power as an event of world historical significance, on the same level as the astonishing rise of Meiji Japan in the late nineteenth century

8. Chen Chieh-hsien 陳捷先, “Jiu Manzhou dang shulüe” 舊滿洲檔述略, in JMZD, vol. 1, 1-56. The Qianlong-reign editors arranged the volumes in the sequence drawn from the popular primer Qianziwen 千字文 (Thousand Character Text), omitting the third character xuan. Some of the bounded volumes had not been marked with a character.

9. For a comprehensive study of language learning in Qing China (broadly defined), see Mårten Söderblom Saarela, "Manchu and the Study of Language in China (1607-1911)" (PhD diss., Princeton University, 2015).

10. See Pamela Crossley, A Transluscent Mirror: History and Identity in Qing Imperial Ideology (Berkeley: University of California Press, 2002), esp. 133-76. Also see Chen Chieh-hsien, Manzhou congkao 滿洲叢考 (Taipei: Guoli Taiwan Daxue wenxueyuan, 1963); Xue Hong 薛虹 and Liu Housheng, “'Jiu Manzhou dang' suo ji Da Qing jianhao qian de guohao" 《 旧满洲档》所记大清建国前的国号, Shehui kexue jikan 社会科学集刊67.2 (1990): 83-90. 
bilingual documents (Part A, ff. 1-28) are followed by a set of very similar documents (Part B, ff. 29-41) that discuss many of the very same officers' battle wounds but are Manchu-only without any Chinese annotations. Both Parts A and B are written on clean, regular-sized Korean paper. By contrast, ff. 42-98 (Part C) are of the chronicle type and clearly dated to Tianming 9 (1624), also Manchu-only, and scribbled on both sides of reused Ming official documents, with the size of the sheets varying a great deal. As such, the format and content of Parts A and B stand apart from the rest of Hanzidang as well as the great majority of the rest of Old Manchu Archive. In his pioneering study of the Hanzidang published in 1985, Matsumura Jun 松村潤 fully transcribed and translated Part A of the Hanzidang, noting repetitions with Part B, but did not compare them in detail. ${ }^{11}$ Building on Matsumura's work, I compare Parts A and B in greater detail and offer some tentative explanations as to why such a non-identical duplicate was made and preserved.

My primary argument is that the peculiar features of Hanzidang's bilingual documents reflect the importance of managing rank-and-file officers during the formative period of the Latter Jin state. Historians have used the Old Manchu Archive to elucidate the intricate power game among Jurchen leadership, revealing bitter internecine fighting among imperial relatives, and the rituals designed the manage them. ${ }^{12}$ Folios 1-41 of Hanzidang shed light on the similarly pressing need to use documentation to effectively administer mid- and lower-ranking military personnel. Here I borrow insights from Katō Naoto's 加藤直人 recent work on the pre-Conquest “escapee archives" (taoren dang 逃人檔), and his discussion of the specific historical conditions that created the archival documents (dangse) and negotiated their functions. ${ }^{13}$ The acts of "writing" (Ma. arambi, meaning "to write," also "to make") and recording (Ma. ejembi, related to the act of rulers [ejen]) archival documents constituted a vital part of what Thomas Conlan, in reference to state-building in Japan, has called the "organizational technology" of a fledgling regime. Comparisons of the Latter Jin state with other militarized societies in early modern Northeast Asia should be further explored. ${ }^{14}$

From the perspective of the rank-and-file members of the Jurchen state, the existence of bilingual documents in the Hanzidang should not be read as the coexistence of two clear-cut identities (Manchu vs. Chinese), but as a product of a polyglot vernac-

11. Matsumura Jun 松村潤, “Kanjitō kanyaku chokusho” 寒字檔漢訳勅書, Minshinshi ronkō 明清史論考, ed. Matsumura Jun (Tokyo: Yamagawa shuppansha, 2008), 268-309.

12. See Roth Li, "State-Building," 44-46; Macabe Keliher, "The Problem of Imperial Relatives in Early Modern Empires and the Making of Qing China," American Historical Review 122, no. 4 (2017): 1001-37.

13. Katō Naoto 加藤直人, Shindai monjo shiryō 清代文書資料の研究 (Tōkyō: Kyūko Shoin, 2016), 294, and passim; Katō Naoto, ed., Tōjintō 逃人檔 (Tōkyō: Tōhoku Ajia Bunken Kenkyūkai, 2007).

14. Thomas Conlan, "Instruments of Change: Organizational Technology and the Consolidation of Regional Power in Japan 1333-1600," in War and State Building in Medieval Japan, eds. John Ferejohn and Frances Rosenbluth (Stanford: Stanford University Press, 2010), 124-58. See also Evelyn Rawski, Early Modern China and Northeast Asia: Cross-Border Perspectives (Cambridge: Cambridge University Press, 2015); Masato Hasegawa, "War, Supply Lines, and Society in the Sino-Korean Borderland of the Late Sixteenth Century," Late Imperial China 37.1 (June 2016): 109-52. 
ular culture intelligible to the "cultural chameleons" who flocked, voluntarily or not, to join the Manchu cause in the 1610s and 1620s. ${ }^{15}$ In the broader Liaodong region, the militarizing communities only gradually took on a more uniform outlook bearing many signature institutions of Manchu administration. A second argument of this paper uses the privilege and ranks granted in the Hanzidang documents to highlight the indebtedness of early Manchu military administration to existing Ming ranks and rules of granting exemption of service to elite members of the society. Tellingly, the edicts do not mention banners $(g \bar{u} s a)$ as units of organization, but companies (niru) only in Part B, not in Part A. Contrary to how Qing dynastic history depicted the pre-conquest period, the Hanzidang documents as well as their duplicate copy reveal how Manchu military administration took shape as a malleable system situated at the confluence of Ming and Mongol military cultures. ${ }^{16}$

The final sections of this paper look beyond the Hanzidang to discuss the overall significance of archive-making (dangse arambi) in the peculiar context of pre-Conquest Manchu state, building on Devin Fitzgerald's discussion of the neologism dang'an in this era. ${ }^{17}$ Rising imperial ambitions under Hong Taiji's rule in the late 1620 s and 1630 s created what Giovanni Stary called the "autochthonous historiography" of the Jurchens. ${ }^{18}$ This was the period when earlier documents were systematically scrutinized and, in many cases, heavily edited and redacted, by the newly founded Historiographical Office (Guoshi guan 國史館) in Mukden, motivated by the anticipated compilation of dynastic history. It is thus quite remarkable how the battle wound registers in the Hanzidang survived this round of scrutiny to remind us of the administrative functions of archive-making and the persistent power of documentation to shape lives beyond the upper strata of government.

\section{Feye / Beye: Wounds and Bodies}

The twenty-two edicts (ejehe) recorded on the twenty-eight pages of Part A of Hanzidang document the type, number, and geographical location of battle wounds for a total of 228 individuals. Each edict starts with "the Khan says" (Han hendume), line

15. Cited in Crossley, A Translucent Mirror, 47-48.

16. Mark C. Elliott, The Manchu Way: The Eight Banners and Ethnic Identity in Late Imperial China (Stanford, CA: Stanford University Press, 2002), 39-88; David Porter, "Ethnic and Status Identity in Qing China: The Hanjun Eight Banners" (PhD diss., Harvard University, 2018); Qingchao qiren yu guojia zhidu gongzuo fang 清朝旗人與國家制度工作坊, “Can Han zhuo Jin" de zai sikao「參漢酌金」的再思考 (Taipei: Wenshizhe chubanshe, 2016).

17. Devin Fitzgerald, "Research Note: Between Paper and Wood, or the Manchu Invention of the Dang'an," Saksaha 13 (2015): 75-80.

18. Giovanni Stary, Manchu Studies: An International Bibliography: 1988-2002 (Harrassowitz Verlag, 2003), 672-82; Qiao Zhizhong 乔致忠, “Hou Jin Manwen dangce de shengchan jiqi shixue yiyi” 后金满文档册的生产及其史学意义, Shehui kexue zhanxian 社会科学战线 (1994.3): 155-60. 


\begin{tabular}{lllc}
\hline Edict number & Number of sheets & Leading official & $\begin{array}{c}\text { Number of individuals } \\
\text { discussed }\end{array}$ \\
\hline 1 & 1 & Eidu & 11 \\
2 & 2 & Bantasi & 12 \\
3 & 2 & Cergei & 13 \\
4 & 1 & Bolhoji ecike & 12 \\
5 & 1.5 & Nihari & 14 \\
6 & 1.5 & Hara & 15 \\
7 & 1 & Dajuhū & 10 \\
8 & 1 & Tumei & 2 \\
9 & 1 & Abtai & 12 \\
10 & 1 & Boihon & 6 \\
11 & 1.5 & Janggalji & 14 \\
12 & 1.5 & Tumburu & 14 \\
13 & 1 & Susalan & 2 \\
14 & 1 & Irešen & 6 \\
15 & 2 & Jaisa & 17 \\
16 & 1 & Unahalai & 13 \\
17 & 2 & Jambulu & 13 \\
18 & 1 & Hūsitun & 5 \\
19 & 1 & Sose & 9 \\
20 & 1 & Nikan & 10 \\
21 & 1 & Bahi & 5
\end{tabular}

elevated, and proceeds to discuss battle wounds and corresponding rewards for two to seventeen individuals (Table 1). Each group begins with a higher-ranking official who received the highest reward, albeit without calling the person the "captain of the company" (nirui ejen), and the terms güsa or niru never appear in the edicts. With two exceptions (edicts 6 and 12), each edict starts on a new piece of paper, even though it meant leaving considerable blank space at the end of the previous edict. It appears to be the case that the khan (Nurhaci) was going through the company-like groups one-byone, reading from an existing register compiled for the occasion. ${ }^{19}$

Parallel Chinese translations only appear for the description of battle wounds and the reward, but not the khan's personal remarks or additional notes in which the rules of reward are explained (see the next section). In many cases, the Chinese translation of the first entry in an edict appears at the very end of the previous edict, indicating that the Chinese translations were added after Manchu edicts were copied and compiled into a booklet. There are also clear traces of editing and deletion affecting both Manchu and Chinese text, which suggests that both languages were read and edited in a parallel manner.

At first glance, the choice of Chinese characters in rendering personal and place

19. Folio numbers of the Hanzidang here follow MWYD, vol. 4, 99-237 (hereafter HZD). In JMZD, the facsimile of Hanzidang corresponds to vol. 4, 1695-1837. Note that folio 99 is reproduced in MWYD but not JMZD. 
names is frequently quite vulgar, as if the scribe or translator did not care at all whether names looked good or decorous in written Chinese (e.g. Ma. Otonggo written as Ch. 惡通果, using the character $e$ 惡, "bad, offensive, etc."). Homonyms (for example lu 錄 and $l u$ 祿, zhen 陣 and zhen 鎮, shang 傷 and shang 上) were used interchangeably, suggesting that the scribe knew Chinese well as a spoken language but sometimes was uncertain or indifferent with regards to the use of specific characters. After writing out a place name such as Ula, the translator would often add a side note indicating the term as a "place name" (diming 地名), which suggests a certain lack of familiarity with these Chinese terms. At the same time, however, the translator or scribe also demonstrated considerable literacy in a popular sense, even to the extent of overdramatizing what was appropriate to say. For example, the Manchu term han (khan) was always rendered in Chinese as Huangdi 皇帝 (emperor), even though technically Nurhaci had not yet assumed any imperial persona yet. In Manchu, the Khan simply "says" (hendume), whereas the Chinese version used the honorific form of "imperial edict" (chiyu 敕諭). ${ }^{20}$ The translator also went out of his way to translate Nurhaci"s "son-in-law" (efu) as "imperial son-in-law in the Eastern Palace" (Donggong fuma 東宮付 [sic] 馬). ${ }^{21}$ The Chinese translation evoked the well-known metonymic move of referring to the imperial heir by his cosmic residence in the "Eastern Palace," but conflated the term with "imperial sonin-law" who normally would not aspire to become an heir in the Chinese context. This indicated that the scribe or translator was interested in creating documents in an "imperial" manner that he probably had learned in a performative setting such as popular drama or fiction, but not Ming official culture. The use of both Chinese characters and Manchu script in writing out these documents was not considered a problem. Rather, Part A of the Hanzidang reveals a vernacular sphere of communication that might be characterized as polyglot and fluid.

The battles mentioned in Hanzidang had been fought early on during Nurhaci's conquest of rival Jurchen tribes at Hejige (1593), Hada (1599), Akiran (1604), Hoifa (1607), Ihan alin (1608), Hūlha (1609), Yaran (1610), Jakūta (1611), and finally the defeat of Ula (1613). ${ }^{22}$ Hostility toward the Yehe was clearly building up, and some officers are recorded in the Hanzidang as having been sent to the Khalkha Mongols, likely in search of an alliance. A man named Hahana, for instance, was praised for "having killed a Yehe man as he went in defense of the Mongol road." 23 All evidence suggests that the edicts are likely to have been made between 1616-1619, in all probability as a gesture to reward loyal soldiers after Nurhaci became Khan in 1616, but prior to the 1619 Battle of Sarhū, where Nurhaci achieved a decisive victory over the Ming-Yehe-

20. HZD, 1a.

21. HZD, 20

22. Roth Li, "State-Building before 1644," 25-34. See also MWLD, 4 (Hoifa), 5 (Ihan alin), 8 (Hūlha), 12 (Ula), and 52 (Yaran).

23. HZD, 21. Hahana monggoi yun de tosome genefi yehei niyalma be waha seme / 哈哈那在孟古路上遇拽黑人廝殺了. 
Korean alliance. Tellingly, battle wounds caused by firearms, which had been heavily deployed by the enemy at Sarhū, were not mentioned at all. ${ }^{24}$

Instead, the world of war and violence in Hanzidang was one dominated by arrows and other cold weapons. The typology of battle wounds taken into account reveals a certain way of reading the bodies of enlisted men in the context of a militarized (and militarizing) society. A typical entry concerns a man named Ilden:

Ilden ulade emgeri gidalabuha emgeri langtulabuha emgeri gabtabuha seme...

亦兒鄧元喇（地名）陣上刺一鎗又打一杜子又中一箭25

At the battle of Ula, Ilden was stabbed with a spear (gidalabuha) one time, hit by a heavy stick (langtulabuha) one time, and shot by an arrow (gabtabuha) one time.

Most entries emphasized the number of wounds (feye) itself:

Weji ulade juwe feye gidalabuba emu feye sacibuha seme...

兀吉在兀喇刺二鎗砍上一處 ${ }^{26}$

Weji, at Ula, had two wounds by being stabbed and one wound by being cut.

Stabbing by spears, hitting by sticks, cutting by (presumably) swords, and arrow-shots constituted four basic types of wounds in Hanzidang. Among those, arrow wounds were so common that the verb gabtabumbi (to be shot by an arrow) was frequently omitted:

Looja hoifade eти feye ulade emu feye baha...

老張在迴扒（地名）鎮中仲一箭在兀喇（地名）仲一箭 27

Looja, at Hoifa, had one wound; at Ula, had one wound.

Without the parallel Chinese translation that specified "arrow" (jian), we would not have been able to tell from Manchu alone what kind of wound (feye) Looja got (baha). The danger of arrow shots has been rendered vividly in another soldier's case:

24. Nicola di Cosmo, "Did Guns Matter? Firearms and the Qing Formation" in The Qing Formation in World-Historical Time, ed. Lynn Struve (Cambridge, Mass: Harvard University Press, 2004), 121-66.

25. HZD, 4a. Here and below, the Chinese text is quoted verbatim from Part A of HZD. Double-lined notations (where the scribe marked words as place names) are rendered in parentheses here and below. All translations are mine.

26. HZD, 1 b.

27. HZD, 1b-2a. 
Jafuni ihan alinde orin ilan feye baha. ninggun feye yali dahabi...

扎扶你亦哈阿嶺陣上中二十三箭只六箭至肉裏 28

Jafuni, at Ihan Alin [the Ox mountain], obtained twenty-three wounds, only six of them reached the flesh.

Jafuni must have been clad in a set of durable armor. Arrow shots that did not penetrate the flesh (yali) were seen as somehow less significant. Meanwhile, battle injuries suffered by one's horse (morin) were also mentioned, likely owing to the heavy emphasis on cavalry in Manchu military culture. For instance, Bantasi, the leading officer mentioned in the second edict, only had his horse "stabbed once" but still received promotions (Bantasi ulade morin emu feye gidalabuha seme). ${ }^{29}$ Elsewhere in the documents, more debilitating wounds such as the loss of eyesight (yasa ehe ohobi), as well as hand or finger injury (gala sacibuha /šumuhun sacibuha), also appear a few times. ${ }^{30}$ The selective focus on eyes and hands again may have been due to the primary importance of archery in early Manchu warfare.

The examples above give an idea of the general tone of Hanzidang, Part A (ff. 128). The Manchu word feye, a word with cognates in other Tungusic languages, means "wounds" but also "key points (a strategic stronghold)."31 The examination of wounds as a way of visualizing a soldier's valor appears to have been an established practice at least throughout Nurhaci's reign. In 1619, Nurhaci ordered the captains of various companies (niru) to supervise their soldiers. For those who "stood far away at the end of a row, and do not fight with all their might," even if they "bear wounds, it does not count as merit." ${ }^{32}$ Although the documents in Hanzidang did reward someone who merely "fought a battle" (Ma. dain de afaha; Ch. shang zhen le 上陣了), as well as people who specialized in various occupations, including a "much-deployed" (taküraha ba labdu 因多差用使之處) shaman and many scholars (baksi), most individuals received recognition according to their battle wounds. ${ }^{33}$

The documents do not offer any hint that actual physical examinations of battle wounds were conducted to make these documents. Many of the battles had been fought decades earlier, and the wounds inflicted there would have become quite old scars by 1616. Many men documented here had already been killed (bucehe) at those

28. HZD, 8a-8b.

29. HZD, 2a.

30. HZD, 19 (Sulhio); 20 (Niyahan), and 12 (Akšan).

31. V.I. Tsintsius, Sravnitel'ny̆ slovar' tunguso-man'chzhurskikh iazykov: Materialy k ètimologicheskomu slovariu (Leningrad: 1975-77), 338; I thank Mårten Söderblom Saarela for locating this source for me. José Andrés Alonso de la Fuente, email correspondence with author, November 16, 2019.

32. NGMW, 19.32 (Tianming 4/5-6). 至於遠立隊尾, 戰不盡力者, 縱被傷亦不為功.

33. HZD, 15 (Suiban saman). 
battles. Instead, the documentation of battle wounds is likely to have been conjured by collectively recognized memories, or even preexisting written records. The Hanzidang documents are therefore not pristine records gained firsthand from the reading of bodies, but the commemoration of wounded bodies retrieved from earlier records and living memory.

\section{Caliyan, Weile (Uile): Stipend and Work}

What did the wounded soldiers get in return for their demonstrated loyalty and bravery? Let us consider again the example of Ilden, this time with the complete sentence:

Ilden ulade emgeri gidalabuha emgeri langtulabuha emgeri gabtabuha seme jakūn niyalma
guwehe 亦兒鄧元喇（地名）陣上刺一鎗又打一杜子又中一箭占丁夫八名 ${ }^{34}$

Since at the battle of Ula, Ilden was stabbed with a spear one time, hit by a heavy stick one time, and shot by an arrow one time. He got an eight-person exemption.

What does it mean to be "exempt by eight persons?" The bilingual rendition here was informed by context that was obvious to the translator-scribe, but opaque to us, and not done on a word-for-word basis. The Manchu verb guwembi ("to escape; to exempt") indicates the shirking of responsibilities, whereas the corresponding verb in the Chinese version, zhan ("to take possession of") connotes personal gain on the part of Ilden. Moreover, the Chinese text specified that Ilden's reward involved eight "adult laborers" (dingfu), whereas the Manchu version simply used the generic word for "people" (niyalma). Whereas the Manchu syntax demonstrated considerable flexibility, the Chinese translation was relatively fixed. The recurrence of the Chinese term in various cases helps us ascertain the meaning of niyalma guwehe:

Weihede ilaci jergi beiguwan i caliyan ninggun niyalma

謂黑得三等備禦占丁夫六名 35

Weihede receives the stipend of third-rank captain; six persons. 
Compare with the following two cases of two scholars (baksi) and one grain administrator (duse):

Hakūn be baksi seme duin niyalmai caliyan

哈空外郎占丁夫四名

Hakūn, [on account of his] being a scholar, four persons' stipend.

Hasitu geopi be baksi seme beyei teile

哈失土狗皮外郎占本身

Hasitu geopi, [on account of his] being a scholar, only himself [is exempted].

Wangginu be jeku jafaha duse seme ilaci jergi beiguwan i caliyan ninggun niyalma

\section{王交都司占丁夫六名 ${ }^{36}$}

Wangginu, [on account of his] being the official in charge of granary, third-rank captain's stipend, nine persons.

The examples above all have different Manchu expressions but identical Chinese expression of zhan dingfu $X$ ming. We might conclude that the reward bestowed to Ilden meant that he could enjoy the service of eight adult men, whose obligations toward the state were now "exempted" (guwehe) and contributed instead to Ilden's "money and grain" (qianliang). From the example of the scholar Hasitu geopi, we can see that those who enjoyed the service of others were by default exempt from service themselves, and that the status as a baksi conveyed the minimal benefit for himself (beyei tele), although for some unknown reason another baksi received much more (four men's labor).

The decision over service exemption as a reward was not made in a haphazard way. As the case of Weihede indicated, "six persons' exemption" constituted the equivalent of the stipend of a "third-rank captain." The document, along with other records in the HZD, indicates a fairly stable "pay-chart" of military ranks adopted from the Ming (Table 2). Some people might receive a higher title while still getting a lower stipend:

In addition, an "explanatory" passage repeatedly showed up in virtually all twentytwo edicts in Manchu (but not translated to Chinese):

36. All three examples are in HZD, 15. 
Table 2: Ranks and stipend listed in Hanzidang

\begin{tabular}{|c|c|c|}
\hline Name & Title (Ma. hergen) & Stipend \\
\hline Eidu & sumingguwan 總兵官(brigade general) & $\begin{array}{l}100 \text { niyalma i caliyan jembi } \\
\text { (benefit extends for three generations } \\
\text { down to his grandson) }{ }^{1}\end{array}$ \\
\hline Boilhoci ecike & $\begin{array}{l}\text { jai jergi sanjan i caliyan 二等參將 (second-rank } \\
\text { lieutenant-colonel) }\end{array}$ & 22 niyalma \\
\hline Nikari & uju jergi iogi i caliyan 一等游擊 (first-rank major) & 16 niyalma ${ }^{2}$ \\
\hline Hara daise & $\begin{array}{l}\text { fujiyang ilaci jergi iogini caliyan 副將三等游擊 } \\
\text { (colonel's rank; third-rank major's stipend) }\end{array}$ & 12 niyalma \\
\hline Afuni & ilaci jergi iogini caliyan (third-rank major's stipend) & 12 niyalma \\
\hline Jafuni & $\begin{array}{l}\text { uju jergi beiguwan i caliyan 頭等備禦 (first-rank } \\
\text { captain) }\end{array}$ & 10 niyalma $^{3}$ \\
\hline Ilden, Turgei, Arai & $\mathrm{n} / \mathrm{a}$ & 8 niyalma \\
\hline Darungga, Otonggo, & $\mathrm{n} / \mathrm{a}$ & 7 niyalma \\
\hline Weihede & $\begin{array}{l}\text { ilan jergi beiguwan i caliyan (third-rank captain's } \\
\text { stipend) }\end{array}$ & 6 niyalma \\
\hline Kambulu & $\mathrm{n} / \mathrm{a}$ & 5 niyalma i caliyan \\
\hline Fakūna & $\begin{array}{l}\mathrm{n} / \mathrm{a} \text {, cansun i caliyan 千總 } \\
\text { (lieutenant's stipend) }\end{array}$ & 4 niyalma \\
\hline
\end{tabular}

1. Translation of titles here and below are based primarily on H.S. Brunnert and V.V. Hagelstrom, Present Day Political Organization of China (Shanghai: Kelly and Walsh, 1912), 340.

2. HZD, 1 a.

3. HZD, 6b. Ereci julesi gung gaici geli wesibumbi; gung gairakūci ere caliyan kemuni bimbi.

Emu cansun de duin niyalma. ilan basun de ilata niyalma. ilan šopu de juwete niyalma. han i hecen de tehe uksin i niyalma karun duka faksi de juwete niyalma. sele wase de ilata niyalma. tai de duin niyalma ulgiyan de ninggun niyalma. ${ }^{37}$

To the one lieutenant (cansun 千總), four persons; to the three sub-lieutenants (basun 把總), three persons each; to the three castle guards (šopu 守堡), two persons each; the armored people that stayed in the Khan's city, the detectives, the gatekeepers, and the artisans, two persons each; the blacksmith and the tilemaker, three persons each; relay station [employees], four persons; swineherds, six persons.

In their annotations, the Qianlong-era editors explained that ulgiyan de ninggun niyalma meant that six people were assigned the pivotal task of raising livestock. ${ }^{38} \mathrm{We}$ might rephrase it to say that the swineherd's job is "worth" six persons, whose labor by definition was exempted from the state. The early Manchu state took over the Ming military ranks and reassessed their meaning together with other specific needs for expertise, including special guards, artisans and pig keepers.

37. HZD, 1b.

38. NGMW, 17.351. 
The majority of soldiers documented in Hanzidang, however, did not receive any rank that came with a fixed amount of stipend for their battle wounds. Take the example of Weji:

Weji ulade juwe feye gidalabuha emu feye sacibuha seme juwan ilan yan i uile waliyambi

\section{兀吉在兀喇刺二鎗砍上一處十三多之錄 39}

Weji, at Ula, had two wounds by being stabbed and one wound by being cut. The work of thirteen taels of silver is being waived.

The keyword here is uile (Standard Ma. weile), which originated from Mongolian üyile meaning "work; act; employment, service," with a secondary sense of "crime" that probably arose later. ${ }^{40}$ In his study of Hanzidang, Matsumura Jun translated the sentence above as Weji being "exempt from thirteen taels' offense," a decision with which the Chinese translators of MBRT concurred. Here I suggest that it would be more appropriate to interpret uile here in the former sense (e.g. weilembi "to work"; weilen "work"; weile-i baita "constructions" [Ch. gongcheng 工程]), as it was likely service but not crime that became monetized here. Furthermore, the translation of uile as punishment is difficult to square with the fact that 14 of the 228 individuals discussed in Part A of the Hanzidang had in fact been killed long ago at battles, but the "waiving" (waliyambi) of their uile persisted after death:

Daimbulu hejige de bucehe ... juwan nemute yan i uile waliyambit1

大卜錄駭吉革 (地名) 陣上死了 ... 每人十一多之錄

Daimbulu died at the battle of Hejige ... (along with others) he gets eleven taels of work waived.

The meaning of "work, service" also works well in another sentence in Part B of Hanzidang:

Han hendume ulai tumei niru be duin aniya oho manggi uilere alban de tebukini seme henduhe. 42

39. HZD, $1 \mathrm{~b}$.

40. See William Rozycki, Mongol Elements in Manchu (Bloomington: Indiana University Research Institute for Inner Asian Studies, 1994), 222; José Andrés Alonso de la Fuente, email correspondence with author, November 16, 2019. 41. HZD, 4a.

42. HZD, 36. Matsumura translated duin aniya oho manggi to "four years after" the defeat of Ula (1613), thereby dating the 
The Khan says: as for the company lead by Tumei of Ula, let them be put into service four years later.

Here the compound uilere alban clearly indicates uilere to be a particular kind of service (alban) collectively owed to the state by a group or family, not punishable wrongdoings. The passage also reveals that the Khan reserved the power to put an entire company under uilere alban or suspend it for any arbitrary duration of time. It is this service that was measured by silver taels, not crime.

Again, an untranslated explanatory sentence in the Hanzidang sought to clarify these rules:

niyalma guwehe niyalmade menggun i uile nakaha. niyalma guwehe akü niyalmade menggun $i$ uile kemuni waliyambi. ${ }^{43}$

To those who were exempt personally, their monetized work is canceled. To those who were not exempt personally, their monetized work is still waived.

On a note pasted to the margin, the eighteenth-century editors of the Old Manchu Archive also understood this passage to be about some kind of "service tax" (hahai alban). ${ }^{44}$ The important point here is that in this militarized society, men with military service were further divided into two status groups: one with privilege of personal exemption (a total of 50 out of 228), and their monetized work owed to the state (menggun-i uile) was simply canceled (nakaha); the other was without exemption, and their silver duty was merely being "waived" (waliyambi) and could be reinstated anytime. That is to say, the Weji's three battle wounds earned him a lessening of monetized service he owed to the state by thirteen taels. Most entries in Hanzidang involved the lessening of small amounts of silver, rarely exceeding twenty taels. No consistent rules seemed to be in place to convert the number and nature of wounds to the amount of silver. Some suffered more wounds and received less; some only got one arrow shot and received more.

The 228 men covered in the twenty-two edicts were too few to constitute a complete account of all active members of the Latter Jin army. Tumei's company also surely consisted of more than two men who suffered any battle wounds discussed in the edict. In other words, the Hanzidang documents concerned the rank-and-file members of the

whole document to 1617 . Here I suggest that the perfective oho manggi indicates completion of the action in the future, not necessarily time lapsed since the past.

43. HZD, 2a, and passim.

44. NGMW, 17.352 (Tianming 9). gingguleme kimcici. . . sere gisun. ainci hahai alban guwebuhe niyalma de menggun guwebure ejehe šangnakū. hahai alban guwebuhekū niyalma de kemuni menggun guwebure ejehe šangnambi sere günin dere. "As we respectfully investigate... (this sentence) means that for those who have been exempt from the 'labor tax,' they do not get awarded the decree of silver exemption. For those who have not been exempt from the 'labor tax,' they still get the decree of silver exemption." 
Jurchen military below the very top aristocratic elite, but still a worthy minority whose merits were recognized by the state in those edicts. They were likely to have been landowning men, heads of their household put under the uilere alban ("service") measured by silver (menggun). The most favored members of their class received "personal exemptions" that got their uilere alban canceled once and for all; the rest used their exceptional military service, measured by battle wounds, to receive individual deductions to their monetized service that may have derived from agricultural surpluses from their land. It is perhaps not surprising that this is reminiscent of Ming rural society in Liaodong, where the Jurchens had recently become the new overlords in the late 1610s but perhaps could not completely reinvent the social order all at once. The distinction between the "personally exempt" (niyalma guwehe) elite and the rest only resembles that between gentry and commoners in a superficial way, as the reciprocal relationship between state and local elite was forged through military service, not the civil service examinations used in Ming China. We shall see that even the temporary privilege granted to elite officers underwent rapid change in the early 1620s.

\section{Between Parts A and B: Duplication and Adaptation}

Having examined the bilingual documents in Part A (ff. 1-28) of Hanzidang, we now compare them with Part B (ff. 29-41), which is Manchu-only but written on the same type of paper (researchers have identified it as Korean paper, Gaoli zhi 高麗紙)..$^{45}$ There are only nineteen edicts recorded in Part B (three fewer than Part A), and a preliminary comparison shows that despite the initial resemblance, Part B in fact rearranged Part A's content substantially (Table 3):

Although the total number of individuals discussed in Part B gets close to Part A (228), there were many names that were new to Part B. The edict appears more compact, without line breaks in between individuals. The khan's comments on certain extraordinary individuals also differ from those of Part A, suggesting that the overlap between Parts A and B was not just a matter of scribal duplication, but fully directed and supervised by Nurhaci. If, as I suggested, the edicts of Part A were made between 1616-1619, then what new conditions might have prompted Nurhaci to revisit them and issue a new set of edicts?

Again, consider the example of Ilden. In Part B, Ilden's battle wounds were repeated with slight modifications. More importantly, he received a totally different kind of reward:

45. On the procurement and use of Korean paper in JMZD, see Chen Chieh-hsien, "Jiu Manzhou dang shulüe," 5-8. 
Of Wounded Bodies and the Old Manchu Archive

Table 3: Number of individuals recorded in Part B of Hanzidang

\begin{tabular}{lcc}
\hline Edict in Part B & Corresponding content in Part A & Number of individuals discussed \\
\hline 1 & 1 & 13 \\
2 & 3 & 12 \\
3 & 2 & 14 \\
4 & 4 & 14 \\
5 & 9 & 17 \\
6 & 15 & 19 \\
7 & 12 & 15 \\
8 & $7 ; 20$ & 19 \\
9 & 13 & 7 \\
10 & 8 & 0 \\
11 & $21 ; 11$ & 14 \\
12 & 6 & 12 \\
13 & $17 ; 16$ & 22 \\
14 & 18 & 8 \\
15 & 20 & 7 \\
16 & 14 & 7 \\
17 & 19 & 11 \\
18 & 22 & 7 \\
19 & 16 & 9 \\
Total & & 227 \\
\hline
\end{tabular}

Han hendume.. Cergei nirui Ilden ulade emgeri gitalabuha emgeri gabtabuha emgeri langtulabuha seme gung arabi ningguci jergi orin ilan yan i uile waliyambihe. emu yan sunja kiyan faitaha.. orin emu yan sunja kiyan bi...(underlined parts are later additions. See Figure 2, last entry. $)^{46}$

The Khan says.: Ilden of Cergei's Company, got stabbed by a spear once, shot by arrows once, and hit by a stick once at Ula. Thus having made merit, he is sixth rank, with twenty-third taels' worth of work waived. Having canceled one tael and five mace (1.5 taels), there is still twenty-one taels and five mace (21.5 taels) left.

To compare it with Part A:

Ilden ulade emgeri gidalabuha emgeri langtulabuha emgeri gabtabuha seme jakūn niyalma guwehe

亦兒鄧元喇（地名）陣上刺一鎗又打一杜子又中一箭占丁夫八名 ${ }^{47}$

Since at the battle of Ula, Ilden was stabbed with a spear one time, hit by a heavy stick one time, and shot by an arrow one time, he receives an exemption of eight men.

46. HZD, 29b.

47. HZD, 4 a. 


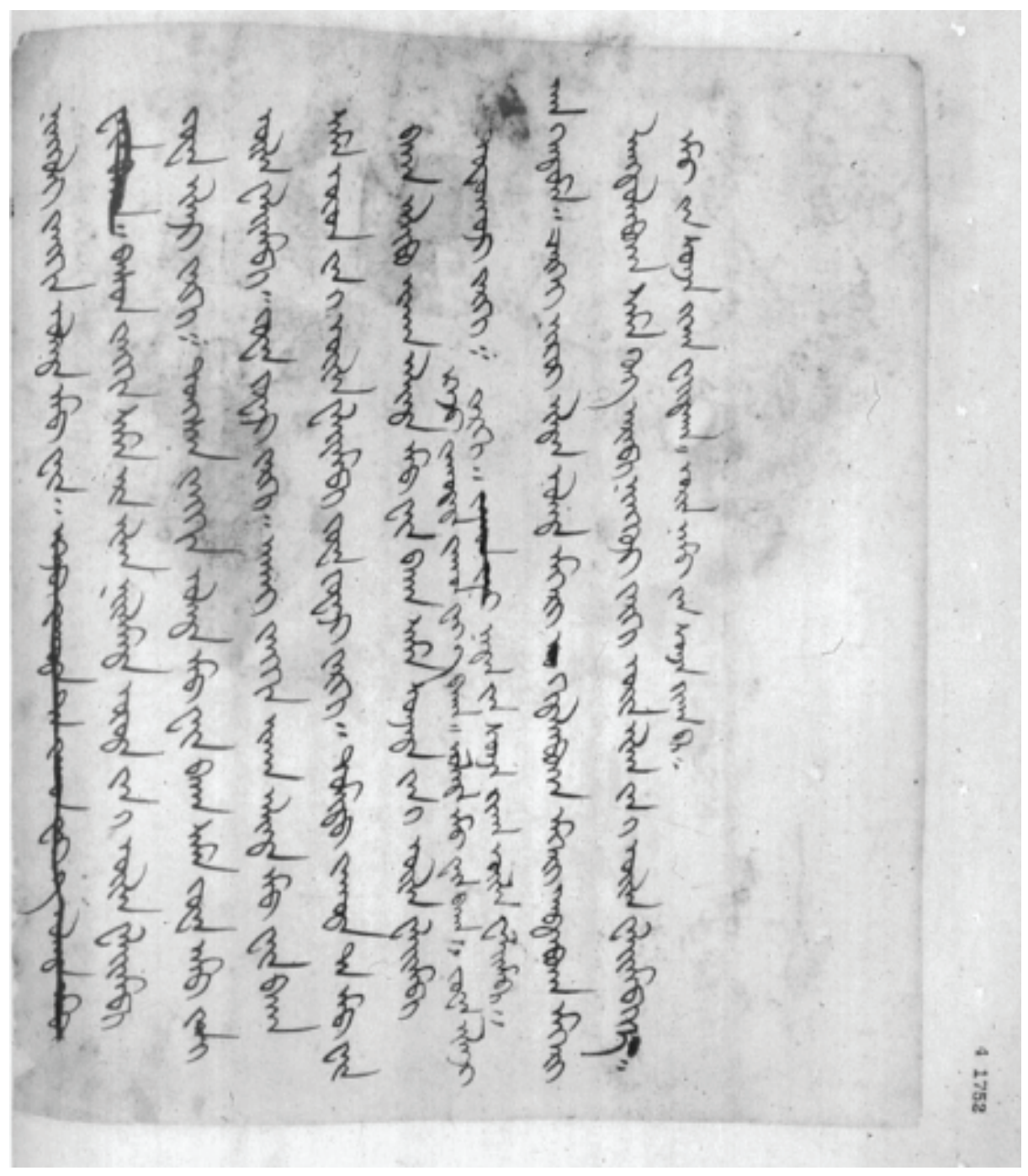

Figure 2. Marks of deletion and revision for llden's ledger in HZD 29b, in MWYD vol. 4, p. 151.

The differences between the two edicts are quite striking. While in Part A, Ilden's name is mentioned in the same edict, following Cergei, without further explanation, Part B spells out that he belonged to the company (niru) of Cergei. Furthermore, whereas in Part A Ilden received the equivalent of eight men's service, in Part B he first got a "sixth rank" (ningguci jergi) on account of the merit he accomplished (gung arabi), and had "twenty-three liang [of silver]" exempted from his monetized work, in the same fashion as the majority of soldiers got in Part A. It did not just happen to Ilden alone. In Part B, everybody got a numerical rank and was given a small amount of work relief, no matter how great their merit. The two-tiered system of Part A was collapsed into one tier in Part B, and now nobody was "personally exempt" (niyalma guwehe) from the numerical 
reckoning with the state. All of the Chinese military titles were also completely erased, replaced by the numerical ranking from one to thirteen.

Upon closer examination, it appears that the last clause of the edict concerning Ilden (underlined in my transcription above) was added as an afterthought, and the word waliyambi "to waive" changed to waliyambihe "was being waived," a change in verb form that allows it to connect to the added clause (see Figure 2). It shows that Part $\mathrm{B}$ was an active ledger, not a fixed text, and that Ilden at some point deducted 1 liang and 5 qian of his merit for some unknown reason, which the scribe duly noted in the books. It is not difficult to tell that Part A was probably created earlier than Part B. The handwriting of both the Manchu and the Chinese therein is rough and unadorned, containing many grammatical errors that were partly corrected later. Furthermore, documents in Part A reiterated rules concerning pay and different awards, indicating that the rules were first added to individual edicts and then compiled together. In Part B, by contrast, the scribes knew exactly what they were doing, and their Manchu handwriting is much more uniform in appearance. They made corrections only to the amount of monetized exemption held by each soldier, not to misspellings. Moreover, the monetized merit earned by each soldier invariably decreased, which suggested that the ledger had been in active use. For example, the soldier named Looja initially got eleven liang of exemption, which was first crossed out and changed to nine, and then eight. ${ }^{48}$ Weji, who received thirteen liang of silver exemption in Part A on account of his three wounds, appears in Part B as follows:

Weji ulade juwe feye gidalabuha emu feye sacibuha seme juwan itan juwe yan i uile waliyambi juwan nemuci jergi..9

Weji, at Ula, had two wounds by being stabbed and one wound by being cut. The duty of thirteen (twelve) taels of silver is being waived.

Wherever there was space at the end of a line, as in the case of Ilden, a sentence was added indicating his "balance." In most cases, the scribe simply made in-line changes to the original number. The need to constantly revisit the record may have been one reason why this set of non-chronicle documents were kept intact. The first set of documents in Part A may have been preserved as references for the initial merit (gung) recognized by the state.

What might have been the institutional context for the creation of Part B alongside Part A? Part A's two-tiered system exploited the familiarity of Ming military titles to residents of the Liaodong region, whereas Part B clearly articulated the company (niru) 
as a socio-military unit, maintaining an egalitarian spirit in disciplining persons of all ranks. In addition, Part B also specified which four officers below the leader (nirui ejen) could use the title of “adjutant" (janggin 章京, occasionally called "the four adjutants" without listing their names). The creation of the niru as well as the four adjutants as assistants to the leader had been documented very early on in the Old Manchu Archive as one of Nurhaci's foundational designs for the Jurchen state. ${ }^{50}$ Yet the absence of institutional terms in Part A, and their reappearance in Part B, suggests that the implementation of Jurchen social structures was by no means so clear-cut. As late as the late 1610s, Nurhaci still had to contend with the titles and ranks borrowed from Ming military culture. Evidence of back-and-forth conversion of Ming military ranks with Manchu titles can be seen in the discussion of such titles in Qingshi gao 清史稿 (Draft History of the Qing), published in 1927. In Tianming 5 (1620), Nurhaci "divided the title of brigade general [Ch. zongbingguan, Ma. sumingguwan] into three ranks, also [divided into three ranks] the titles of colonel, lieutenant-colonel, and major [Ch. fujiang, canjiang, and youji; Ma. fugiyang, sanjan, iogi]. All company leaders [Ma. nirui ejen] were made captain [Ch. beiyu, Ma. beiguwan]. ${ }^{51}$ The record, with a numerical system of 13-15 ranks, matched exactly the record of numerical ranks in Part B. We might thus tentatively date Part B to shortly after 1620, when Nurhaci attempted to standardize the management of mid-ranking military personnel and revisit earlier records of individual merit. This confirms Matsumura Jun's judgment that these documents were created before 1624, and therefore were of separate origins from the clearly dated ff. 42-99 of Hanzidang. Between Parts A and B, the adjustments were as meaningful as the duplications between the two sets of documents.

\section{Nurhaci's Personnel Archive}

Wang Wan 汪琬 in early Qing times made a special note on the term dangzi [dangse] in an epitaph he composed for a Han bannerman:

\section{本朝用薄版五六寸, 作滿字其上, 以代簿籍。每數片輙用牛皮貫之, 謂之檔 子.}

Our dynasty uses thin wooden tablets, five to six inches wide, to write Manchu scripts instead of registry books. Every several tablets would be stringed together with ox hide, and it is called dangzi. ${ }^{52}$

50. NGMW, 19.12 (Wanli 43/11).

51. Zhao Erxun 趙爾巽 et al., Qingshi gao 清史稿 (Beijing: Zhonghua shuju, 1986), juan 117 (zhi 92, zhiguan 4), 3362. 初, 天命五年, 論功序列五爵, 分總兵官為三等, 副將、參將、游擊亦如之, 牛录額真稱備禦

52. Wang Wan 汪琬, Yaofeng wenchao 堯峰文鈔, juan 11, 7b. Manuscript reproduced in Sibu congkan 四部叢刊, ed. Zhang 
Similarly, Yang Bin 楊賓 (1650-1720) noted during his life as the son of an exile in Ningguta:

邊外文字多書於木。往來傳遞者曰牌子, 以削木片若牌故也。存貯年久者曰 檔案。曰檔子。以積累多貫皮條掛壁若檔故也。

Beyond the palisade, texts are mostly written on wood. Those that are passed back and forth are called paizi [plaques], as the wooden pieces are pared thin like plaques. Those that are stored for a long time are called dang'an, or dangzi, for the wooden tablets accumulate to a large number, and are stringed together with hide stripes and hung on the wall, like a crosspiece. ${ }^{53}$

He goes on to ponder on the historicity of writing practices, comparing the Manchu use of dangse with ancient bamboo tablets in the "Central Kingdom":

然今文字之书于纸者亦呼为牌子档子。犹之中土文字。汉以前载在竹简。故 曰简。以韦编贯。故曰编。今之人既书于纸。为卷为部。而犹呼之为编为简 也。

However, nowadays texts written on paper are also called paizi and dangzi. This resembles how texts of the central states [of China] had been recorded on bamboo slips prior to the Han dynasty, and so are called jian [bamboo slips]; the slips were stringed together with reeds, called bian [files]. Whereas people today write on paper, making fascicles (juan) and volumes (bu), but still use the terms of bian and jian. ${ }^{54}$

Both Wang and Yang noted the rich tradition of creating, storing, and referencing written documents among residents "beyond the palisade." They also noted that the neologism dangse originated in a multi-faceted documentary culture that frequently employed media beyond paper, such wooden tablets that were carefully arranged into a dangse..$^{55}$ Going beyond my analysis of the Hanzidang, I now turn to the question of how the idea of dangse, defined as collected files stored in one place, gained traction early on in the expanding regime under Nurhaci. We shall see how the need to manage personnel provided the key context in the numerous occurrences of the word dangse in other parts of the Old Manchu Archive.

Yuanji 張元濟 et al. (Shanghai: Shangwu yinshuguan, 1919), vol. 1697. The quote appeared in a double-lined commentary, indicating that Wang expected his readers to be unfamiliar with the function of dang'se.

53. Yang Bin 楊賓, Liubian jilüe 柳邊紀略, juan 3, 16b. Yang also noted that dang'an was used to screen travelers in and out of Shanhai Pass for any smuggled sable pelt or ginseng. See also Yang Bin, Liubian jilüe, juan 1, 9a-9b.

54. Yang, Liubian jilüe, juan 3, 16 b.

55. For more research on a group of wooden tablets used in military reporting that were dated to 1635, see Li Deqi 李德 啓, Ajige lüe Ming shijian zhi manwen mupai 阿濟格略明事件之滿文木牌 (Beiping: Guoli Beiping gugong bowuyuan, 1935); Michael Weiers, "Zur Registratur der mandschurischen Holztäfelchen," Aetas Manjurica 6 (1998): 251-314. 
In Tianming 6 [1621], for example:

Orin ninggun de. Dangse be dasame tuwafi. Kitanggür be tsanjiyang obuha. Nikasa be. Bucehe niyalma be. Gemu dasame encu dangse araha.

On the $26^{\text {th }}$ day, [the Khan] looked at the archive again and promoted Kitanggūr to the rank of lieutenant-colonel (Ch. canjiang). [He also asked] the Chinese and deceased persons to be copied to another archive. ${ }^{56}$

That is to say, Chinese (nikan) and Jurchens were from now on to be administered in separate documents. Not only were matters of promotion and demotion being decided upon the Khan's own perusal of "archival" documents, he also paid close attention to how the documents were organized and classified.

Again, in Tianming 8 [1623],

Ice jakūn de. Han akū oho hafasa de niyalma šangnara jalin de dangse bithe tuwaci. ${ }^{57}$

On the eighth day, in order to award people to officials who died, the Khan looked at the archival documents. Thereupon,... .

Back in 1619 [Tianming 4], he ordered every ranked officer to make a written oath, declaring allegiance and obedience to the Khan. The written oath was to be reviewed by the Khan, "written in the dangse and received" (han tuwafi dangse de arame gaifi). Future offenses would be checked against their oaths and punished accordingly. ${ }^{58}$

In the early Jurchen regime, promotion and punishment were not matters to be taken lightly. The Hanzidang testifies to how Nurhaci took great pains in individually assessing his officers' military merit (measured primarily by battle wounds) and reviewed their record frequently. The creation and maintenance of dangse was instrumental in how he managed this kind of administrative matters. We see how the silver exemption balance was crossed out and recalculated, and how entire sentences (specific people) were obliterated with a brush stroke (faitaha). For Hūsitun, who showed up for his battle wounds in Part A of Hanzidang, ${ }^{59}$ was later punished on account of dubious activity and erased from the archive:

56. NGMW, 17.130 (Tianming 6/5/26).

57. NGMW, 17.322 (Tianming 8/7/8).

58. NGMW, 17.64-5 (Tianming 4/7/8). akdulaha gisun be gemu han de wesimbu. Han tuwafi dangse de arame gaifi.

59. HZD, 2 b. 
Hūsitun, jeng giyang ni baru ajige jui be dahan benebuhe seme. Orin yan i weile arafi. Ejehe dangse gung faitaha. ${ }^{60}$

Hūsitun, on account of his having delivered the younger child with a young horse in the direction of Zhenjiang (Mao Wenlong's base), establish twenty taels' worth of service and, following that, cancel his merit recorded in the edict archive.

The "ejehe dangse" in which Hūsitun's merit was recorded probably referred to the edicts in Hanzidang. However, in Part B of Hanzidang, Hūsitun seemed to have received an order of rehabilitation:

Han hendume.. Hūsitun juwan aniya oho manggi geren i jergide tekini. ${ }^{61}$

The Khan says, let Hūsitun sit with others after ten years [have passed].

Again the sequence of Hūsitun's punishment and rehabilitation suggests that Part A of Hanzidang was composed before Tianming 6 (1621) and Part B after that. Overall, the documents give the impression that Nurhaci played with the give-and-take of titles so frequently that it must have become a heavy burden on his everyday schedule as khan.

Later during the Tianming reign, Nurhaci began to lay the foundation for a princely council to oversee state affairs, delegating some of the minute management of personnel to this body of collective governance. In 1623, the princely council considered the promotion of Elcibu to the rank of captain (beiyu), which was then "written into the dangse" (dangse de araha). ${ }^{62} \mathrm{~A}$ few days later, the council deliberated and decided to strip several officers of their ranks. Upon hearing the proposal, Nurhaci asked:

Han fonjime. Hergengge niyalma de šangnara dangse. Jakün beise de gemu bio seme fonjiha manggi. Šangnara dangse beise de akū. Emu dangse seme alaha manggi. Emu dangse be jakvn dangse ara. Hergen efuleci. Jakün dangse be sasa efule. Hergen araci. Jakün dangse de sasa ara. Tuttu oci. Baksi sa suwende sain kai seme jakün dangse araha. ${ }^{63}$

The Khan asks, "As for the dangse of giving rewards to people with titles, do the eight princes also have it?" After that, it was told [to the Khan] that "The princes do not have

60. NGMW, 17.170 (Tianming 6/12/9). Hūsitun obtained his title of Major (iogi) on account of his elder brother Yamburi's merit; see NGMW, 17.126 (Tianming 6/5/9).

61. HZD, 39a, compare to the record in HZD, 2. Note that this is another example of an order that was to take effect in the future, with the construction of "oho manggi ... tekini."

62. NGMW, 17.281 (Tianming 8/4/29). Orin uyun de. Elcibu, sabigan be acan beiguwan.. Beise jakūn hošonggo yamun de isaha inenggi fonjifi. Dangse de araha.

63. NGMW, 17.287 (Tianming 8/5/5). 
the dangse of giving rewards. Only one dangse [exists]." After that, [the Khan ordered that] "The one dangse is to be written into eight dangse. If a title is stripped, strip it off in all eight dangse. If a title is granted [written], write it into all eight dangse. In doing so, it is also good for you scholars." Saying this, eight dangse were written [established].

This key passage reveals a critical moment, the duplication of the one and only set of archival documents into eight copies. Just as matters of promotion and demotion were now to be deliberated by a group of councilors, the written record of such actions was to be simultaneously established and updated in each office. The Khan's final remark is especially intriguing. He spoke directly to the "scholars" (baksi sa), who were in front of him recording this very document, and said that the duplication of archives was "a good thing" for them as well. If more hands were needed to copy all these extra documents, it would be a boost to the scholars' status (and remuneration).

The writing of dangse under the early Jurchen regime was not limited to confidential matters overseen by the Khan and a small group of leaders. In 1621, Nurhaci ordered that every company (niru) was to appoint ten people to "write dangse" (dangse araha). ${ }^{64}$ Those documents were then to become the basis for future investigations: in 1625 , Nurhaci ordered a comprehensive inspection (baica) of the documents, to see which company had committed the most offences by theft, and which company had none. ${ }^{65}$ The company's dangse also carried the function of registering adult males fit for military service, and subject to requests for the most up-to-date information at any time. In 1623, an unsuccessful accusation against Wang Zideng, a high-ranking general in charge of iron melting, shed some light on the practice of archival documentation. A letter of treasonous nature, it was reported, was placed "along with all sorts of dangse documents in a big cabinet" (bithe be amba horho de geren dangse bithei suwaliyame bihe). When a messenger came to fetch "documents of the number of male laborers" (hahai ton $i$ dangse bithe), the letter was also discovered to be treasonous. ${ }^{66}$

Upon hearing that, Nurhaci considered the accusation to be absurd. If it were truly a treasonous document, he reasoned, then Wang would have "hidden it elsewhere, in a secret place; how can he hide it by putting it alongside all the dangse documents?" (narhūn bade encu somime asarambi dere. Geren dangse bithei emgi ainu asarambi). Notably, these official documents were considered to be the opposite of "secret" (narhün), stored in an official's cabinet so that it could be consulted if necessary. The battle wound

64. NGMW, 17.140 (Tianming 6/7/19). Juwan uyun de. Emu nirui juwanta niyalma tucibufi. Dangse araha.

65. NGMW, 17.367 (Tianming 10/1/10). Juwan de. Han, jakūn hošonggo ordo de tucifi hendume. Musei gurun i dolo hülha dekdehebi. Wei niru hülhafi weile araha ambula. Wei niru hülhahakü weile arahakübi. Tere be dangsei bithe be tuwame baica seme afabufi. Sunja inenggi baicame wacihiyafi. Baicame wajiha seme wesimbure jakade.

66. NGMW, 17.315 (Tianming 8/6/29). Orin uyun de. Sele urebure ši ceng ni tsan jiyang Wang Dzi Deng be . . bithe be amba horho de geren dangse bithei suwaliyame bihe. Gin iogi niyalma takūrafi hahai ton i dangse bithe gajire jakade. Wang Dzi Deng soktofi dangse bithe gaijara de suwaliyame tucike be baha seme hendumbi. Unenggi cargi ci unggihe bithe oci. Narhün bade encu somime asarambi dere. Geren dangse bithei emgi ainu asarambi. 
registers in Hanzidang were produced during this intense period of archive-making till Nurhaci's death in 1626.

\section{Ara/Ūme: Archive-Making Beyond Historiography}

Let us briefly turn to the latter part of Hanzidang that I have not discussed so far. The 57 folios were written on previously used Ming official documents, sometimes written on the back, sometimes on the margins. It belongs to a type of "court diary" typical in the Old Manchu Archive. Every day, two banners took the responsibility of recording the Khan's whereabouts, including the hour at which he prayed at the shrine; diplomatic letters received and sent; and intricate dances of politics between aristocratic men and women. ${ }^{67}$ The tattered look of those documents notwithstanding, their content carried paramount political significance starting from the very early stage of official historiography sponsored by the Manchu state. Officials in the late 1630s examined each piece of paper, made decisions of whether to copy (Erebe ara "Write this!") or not (Erebe üme "Do not [write] this!"). The process eventually resulted in the sanctioned and sanitized editions of pre-Conquest veritable records (shilu) for Nurhaci's and Hong Taiji's reign periods.

In contrast, ff. 1-41 of the Hanzidang, which had been bound together with those later court diaries for unknown reasons, look impressively pristine, unmarked by the later ambition to write and rewrite dynastic history. They were created and preserved to serve an administrative purpose, mediating each individual's privilege and obligations to the state. At the same time, however, this pristine look is perhaps another illusion. We have already seen how Parts A and B of the Hanzidang were likely to have been copies of even earlier documents that had long been lost, and how they presented quite distinct ways of conceiving and distributing merit, even if the number and type of battle wounds inflicted on one's body remained the same. There is something stubborn in these personnel files that resisted the writing and un-writing of dynastic history, to the extent that it might justify the translation of dangse into "archive," prior to the word dang'an becoming the equivalent of "archive" in the twentieth century.

When the National Palace Museum in Taipei first sent out the pre-conquest Manchu documents for facsimile reproduction in the 1960s, the original of the last page of Hanzidang was reportedly lost. ${ }^{68}$ The loss of the so-called "image of a female corpse" (nüshitu) in the Old Manchu Archive had sparked media attention since then. ${ }^{69}$ If we

67. HZD, 42.

68. HZD, 98a.

69. More recently, a Chinese historian of science pointed out that the body represented was likely to be male, not female. See Han Jianping 韩建平, “Taipei Gugong yishi de nü shi tu: keyi de xingbie” 台北故宫遗失的女尸图: 可疑的性别, Kexue wenhua pinglun 科学文化评论 10.6 (2013): 61-68. 
examine the Ming official document on which the Jurchen scribes wrote, it is clear that the original document was a Ming coroner's report produced in the $28^{\text {th }}$ year of Jiajing reign (1549). Although most of the Chinese text is now illegible, one could tell that the body image represented the corpse being examined, and the report consists of a list of body parts: "two ankles: no cause [of death]; ten fingers: no cause ..." In a strange way, the last part of Hanzidang, which had been written on Ming official documents in the local administration that dealt with dead bodies, came to be bound with the first 41 pages that documented wounds resulting from battles fought for the Jurchen state. I came to study the Hanzidang due to my interest in this image. It turns out that seventy years after it was made, the Ming record of a corpse was lifted out of the files and, by chance, bound together with the documentation of over two hundred officers fighting for the insurgent Jurchen state.

The first and last parts of the Hanzidang also found uncanny resonance in their bilingualism. On the last day of the first month in the year of jiazi (1624), the scholar (baksi) in charge finished off his work and decided to have some fun by writing something else on the empty space left on that piece of Ming official document paper. Marking time with the specific year and month (甲子年正月記), the scholar copied a ditty from Poetry of Scholar Xie (Xie xueshi shi 解學士詩), a popular late Ming anthology attributed to the child prodigy Xie Jin 解縉 (1369-1415):

一直往南去 轉來朝向東

門前有大字 便是董郎中70

Go straight toward the south,

Make a turn, then facing east;

In front of the door are large characters

And that is Doctor Dong's home.

The ditty confronts us with the likely scenario that the person writing the court chronicles for Nurhaci during the first month of Tianming 9 (1624) might have been a native speaker of Chinese, or at least familiar with late Ming vernacular literature. The unintended (and undisciplined) bilingualism at the very end of Hanzidang resonates in an uncanny manner with the bilingual battle wound records, showing how a vernacular, polyglot culture ran deep among rank-and-file members of the early Manchu state that had not yet become the Great Qing. In the 1620s, the scholars who created and managed dangse documents for the khan were not primarily concerned with the moral imperatives of official historiography. Nor was Nurhaci, who toward the end of his life

70. HZD, 98b. 
maintained a tight control over archival records in order to reshape and manage the land and people he conquered, instead of boasting of his own victories.

\section{Bibliography}

\section{Published Archives}

JMZD: Ch'en Chieh-hsien 陳捷先, ed. Jiu Manzhou dang 舊滿洲檔. 10 vols. Taipei: National Palace Museum, 1969.

MBRT: Kanda Nobuo 神田信夫 et al., eds. Manbun rōtō 満文老檔 (Tongki fuka sindaha hergen-i dangse). 7 vols. Tokyo: Toyo Bunko, 1955-63.

MWLD: Manwen laodang 滿文老檔. 2 vols. Zhongguo diyi lishi dang'an guan and Zhongguo shehui kexueyuan lishi yanjiusuo 中國第一歷史檔案館, 中國社會科學院歷史研究所, eds. Beijing: Zhonghua shuju, 1990.

MZYD: Feng Mingzhu 馮明珠, ed. Manzhou yuandang 滿洲原檔. 10 vols. Taipei: National Palace Museum, 2005.

NGMW: First Historical Archives ed. Neige cangben Manwen laodang 内阁藏本满文老档. 20 vols. Shenyang: Liaoning minzu, 2009.

\section{Other Works Cited}

Bartlett, Beatrice S. "Saving China’s History: The Discovery and Debate Concerning the Sorting and Arranging of the Qing Archives, and Their Eventual Dispersion, 1912-1949.” Lecture at Princeton University, March 8, 2016.

—_. “Qingdai dang'an lunshu de huigu: 1616-1999 清代檔案論述的回顧: 1616-1999.” In Fu an de lishi: Dang'an kaojue yu Qing shi yanjiu 覆案的歷史: 檔案考掘與清史研究, edited by Chen Hsi-yuan 陳熙遠, 1-58. Taipei: Academia Sinica, 2013.

Brunnert, H.S. and V.V. Hagelstrom. Present Day Political Organization of China. Shanghai: Kelly and Walsh, 1912.

Chen Chieh-hsien 陳捷先 [Chen Jiexian] 陳捷先. Manzhou congkao 滿洲叢考. Taipei: Guoli Taiwan daxue wenxueyuan, 1963.

Conlan, Thomas. "Instruments of Change: Organizational Technology and the Consolidation of Regional Power in Japan 1333-1600." In War and State Building in Medieval Japan, edited by John Ferejohn and Frances Rosenbluth, 124-58. Stanford: Stanford University Press, 2010.

Crossley, Pamela. A Translucent Mirror: History and Identity in Qing Imperial Ideology. Berkeley: University of California Press, 2002.

Di Cosmo, Nicola. "Did Guns Matter? Firearms and the Qing Formation.” In The Qing Formation in World-Historical Time, edited by Lynn Struve, 121-66. Cambridge, Mass: Harvard University Press, 2004.

Dong, Madeleine Yue. "How to Remember the Qing Dynasty: The Case of Meng Sen." In The Politics of Historical Production in Late Qing and Republican China, edited by Tze-ki Hon and Robert J. Culp, 323-74. Leiden: Brill, 2007.

Elliott, Mark C. The Manchu Way: The Eight Banners and Ethnic Identity in Late Imperial China. Stanford, CA: Stanford University Press, 2002. 
Fitzgerald, Devin. "Research Note: Between Paper and Wood, or the Manchu Invention of the Dang'an.” Saksaha 13 (2015): 75-80.

Guang-lu 廣祿 and Li Xuezhi 李學智. “Qing Taizuchao Lao Manwen yuandang yu Manwen laodang zhi bijiao yanjiu” 清太祖朝老滿文原檔與滿文老檔之比較研究. In Lao Manwen yuandang lunji 老滿文原檔論集, edited by Li Xuezhi, Appendix 1 (165 pp.). Taipei: Academia Sinica, 1971.

Han Jianping 韩建平. “Taipei Gugong yishi de nü shi tu: keyi de xingbie” 台北故宫遗失的女尸 图: 可疑的性别Kexue wenhua pinglun 科学文化评论10.6 (2013): 61-68.

Hasegawa Masato. "War, Supply Lines, and Society in the Sino-Korean Borderland of the Late Sixteenth Century." Late Imperial China 37.1 (June 2016): 109-52.

Kanda Nobuo 神田信夫. "From Man-wen lao-tang to Chiu Man-chou tang." Memoirs of the Research Department of the Toyo Bunko 38 (1980): 71-94.

Katō Naoto 加藤直人. Shindai monjo shiryō no kenkyū 清代文書資料の研究. Tōkyō: Kyūko shoin, 2016.

—. Tōjintō 逃人檔= Ubašame ukame jihe, museingge ukame genehe dangse. Tōkyō: Tōhoku Ajia Bunken Kenkyūkai, 2007.

Keliher, Macabe. "The Problem of Imperial Relatives in Early Modern Empires and the Making of Qing China." American Historical Review 122.4 (2017): 1001-37.

Kim Tu-hyŏn 金斗鉉. Manmun nodang kwa Ku manjudang taejop'yo: T'aejojo 滿文老檔 舊滿洲檔 對照表: 太祖朝 Ulsan Kwangyŏksi: Ulsan Taehakkyo ch'ulp’anbu, 2010.

Li Deqi 李德倁. Ajige lüe Ming shijian zhi manwen mupai 阿濟格略明事件之滿文木牌. Beiping: Guoli Beiping gugong bowuyuan, 1935.

Liu Housheng 刘厚生. Jiu Manzhou dang yanjiu 旧满洲档研究. Changchun: Jilin wenshi chubanshe, 1993.

Matsumura Jun 松村潤. “Kanjitō kanyaku chokusho” 寒字檔漢訳勅書. In Minshinshi ronkō 明清史 論考, 268-309. Tokyo: Yamagawa shuppansha, 2008.

Pang, Tatiana A. "The Manchu Script Reform of 1632: New Data and New Questions." Studia Orientalia 87 (1999): 201-6.

Pang, Tatiana A., and Giovanni Stary. Manchus versus Ming: Qing Taizu's "Proclamation" to the Ming Dynasty. Wiesbaden, Harrassowitz, 2010.

- New Light on Manchu Historiography and Literature: The Discovery of Three Documents in Old Manchu Script. Wiesbaden, Harrassowitz, 1998.

Porter, David. "Ethnic and Status Identity in Qing China: The Hanjun Eight Banners." PhD Dissertation, Harvard University, 2018.

Qingchao qiren yu guojia zhidu gongzuo fang 清朝旗人與國家制度工作坊, ed. “Can Han zhuo Jin” de zai sikao「參漢酌金」的再思考. Taipei: Wenshizhe chubanshe, 2016.

Qiao Zhizhong 乔致忠. “Hou Jin Manwen dangce de shengchan jiqi shixue yiyi” 后金满文档册的生 产及其史学意义. Shehui kexue zhanxian 社会科学战线 1994.3: 155-60.

Rawski, Evelyn. Early Modern China and Northeast Asia: Cross-Border Perspectives. Cambridge: Cambridge University Press, 2015.

Roth Li, Gertraude. "State-Building Before 1644." In The Cambridge History of China, Vol. 9, Part 1, edited by Willard J. Peterson, 9-72. Cambridge: Cambridge University Press, 2002.

Rozycki, William. Mongol Elements in Manchu. Bloomington: Indiana University Research Institute for Inner Asian Studies, 1994.

Saarela, Mårten Söderblom. "Manchu and the Study of Language in China (1607-1911)." PhD diss., Princeton University, 2015.

Stary, Giovanni. Manchu Studies: An International Bibliography: 1988-2002. Wiesbaden: Harrassowitz Verlag, 2003. 
Tsintsius, V.I. Sravnitel'ny̆ slovar' tunguso-man'chzhurskikh iazykov: Materialy k etimologicheskomu slovariu Leningrad: $1975-77$.

Wakeman, Frederic. The Great Enterprise: The Manchu Reconstruction of Imperial Order in SeventeenthCentury China: University of California Press, 1985.

Wang Wan 汪琬. Yaofeng wenchao 堯峰文鈔. Manuscript reproduced in Sibu congkan 四部叢刊, edited by Zhang Yuanji 張元濟 et al, vols. 1688-1707. Shanghai: Shangwu yinshuguan, 1919.

Weiers, Michael. "Zur Registratur der mandschurischen Holztäfelchen über Ajiges Invasion der Ming im Jahre 1636.” Aetas Manjurica 6: 251-314. Wiesbaden: Harrassowitz, 1998.

Xie Guozhen 謝國楨. Qing kaiguo shiliao kao 清開國史料放 Beiping: Guoli Beiping tushuguan, 1931.

Xue Hong 薛虹 and Liu Housheng 刘厚生. “Jiu Manzhou dang suo ji Da Qing jianhao qian de guohao” 《旧满洲档》所记大清建国前的国号. Shehui kexue jikan 社会科学集刊 67.2 (1990): $83-90$.

Yan Chongnian 阎崇年. 'Wu quandian laodang' ji Qianlong chaoben yi yan shuping” 《无圈点老 档》及乾隆抄本译研述评. Gugong bowuyuan yuankan 故宫博物院院刊 1998.3: 32-46.

Yang Bin 楊賓. Liubian jilüe 柳邊紀略. Hezhai congshu edition, 1875-1908.

Zhao Erxun 趙爾巽 et al. Qingshi gao 清史稿. Beijing: Zhonghua shuju, 1986.

Zhuang Jifa. “"Manwen yuandang,' 'Neige cangben manwen laodang' yu Qingchao qianshi de yanjiu” 《 滿文原檔》、《內閣藏本滿文老檔》與清朝前史的研究. In Fu an de lishi: Dang'an kaojue yu Qing shi yanjiu 覆案的歷史: 檔案考掘與清史研究, edited by Chen Hsi-yuan, 59-144. Taipei: Academia Sinica, 2013.

. “Wenxian zuzheng: Manwen laodang yu Qingshi yanjiu 文獻足徵: 滿文老檔與清史研 究.” Manxue yanjiu 滿學研究4 (1998): 85-115. 
